\title{
PEMBATALAN PERKAWINAN AKIBAT POLIGAMI
}

\author{
Oleh: Abd. Holik*
}

\begin{abstract}
Cancellation of marriage isoneway of breaking the bond of marriagewhose requirement and principle are flawed. In the provisions of article 71 letter (a), the Islamic law compilation says that Polygamous marriage can be cancelled if it does not meet the requirement. The main requirement in that provision is there is permit of religious courts. Beside that, in the KHI material making, most of literature used to be base is fiqh Syafiiyyah idea. So, research about the base of provisions of article 71 letter (a) detterminaion use Syafiisfiqh. It is library research .Data is analyzed by content analysis. Then, it use descriptive comperative method patterned deductive reasoning. The research concludes that Article 71 letter a KHI is the result of the framers KHI ijtihad, not legal scholars product Shafi iyyah. Relevance to the Shafi i fiqh schools located in the excavation methodology that focuses on the legal aspects of the achievement of beneficiaries and preventive measures on the incidence of damage.
\end{abstract}

Keywords: Cancellation of Marriage, Polygamous

* Dosen Program Studi Ahwal Syakhsiyyah Fakultas Syari'ah Sekolah Tinggi Islam Bani Fatah Jombang 


\section{Pendahuluan}

Perkawinan merupakan satu permasalahan hukum privat sehingga masuk dalam kategori keperdataan. Dengan adanya perkawinan, timbul suatu hubungan hukum. Persoalan keperdataan menjadi lebar. Antara lain mencakup kewajiban suami istri, hak kepemilikan, status anak, hak kewarisan harta dan lain sebagainya. Di Indonesia, mengenai aturan-aturan perkawinan termaktub dalam Undang-undang Nomor 1 Tahun 1974 Tentang Perkawinan, atau yang disebut dengan Undangundang Perkawinan (UUP), dan Peraturan Pemerintah Nomor 9 Tahun 1975 Tentang Pelaksanaan UUP Tahun 1974.

Sedangkan bagi permasalahan perdata Islam Indonesia, dibentuk suatu dokumen yustisia atau yang lebih dikenal dengan sebutan Kompilasi Hukum Islam (KHI) sebagai tindak lanjut hukum materiil yang tertuang dalam UUP. Dasar hukum KHI adalah Instruksi Presiden Nomor 1 Tahun 1991 yang dikeluarkan pada tanggal 10 Juni 1991. Kemudian ditindaklanjuti dengan Keputusan Menteri Agama Nomor 154 Tahun 1991 mengenai penyebarluasan Kompilasi Hukum Islam. Meskipun sebagian pakar hukum tidak menyatakan KHI sebagai hukum perundang-undangan yang berlaku di Indonesia, namun seluruh jajaran peradilan agama sudah mengakuinya sebagai pedoman yang harus dijalankan dan dipatuhi oleh umat Islam sehingga KHI dapat juga disebut undang-undang Islam. ${ }^{2}$ Menurut Sukris Sunardi, KHI adalah hasil lokakarya para ulama yang dituangkan dalam Instruksi Presiden Nomor 1 Tahun 1991 yang merupakan fakta kebenaran fikih sunni versi mazhab Syafi'i walaupun pada bagian-bagian tertentu ditemukan refleksi-refleksi pemikiran baru untuk mengisi ruang kosong dalam rangka penyesuaian kondisi dan situasi masyarakat Indonesia. ${ }^{3}$ Namun demikian, di antara hal fundamen yang berbeda diantara fikih mazhab Syafi'i dan KHI berkait asas perkawinan. Jika dalam fikih mazhab Syafi’i nuansa asas poligami yang diterapkan, KHI berkebalikan menetapkan asas monogami, sebagaimana tipikal yang ditonjolkan dalam perundangan perkawinan di Indonesia. Konsekwensi logisnya,

\footnotetext{
${ }^{2}$ Warkum Sumitro, PerkembanganHukum Islam di Tengah Dinamika Sosial Politik di Indonesia, (Malang: Bayumedia, 2005), hlm. 190.

3 Sukris Sunardi, Trasendensi Keadilan Hukum Waris dalam Islam Transformatif, (Semarang: Toha Putra, 1991), hlm. 3.
} 
jika terdapat pelangggaran terhadap asas monogami tersebut, pembatalan perkawinan dapat diajukan oleh pihak-pihak tertentu, dan dilakukan sesuai dengan ketentuan perundangan yang berlaku. Lalu, bagaimanakah permasalahan pembatalan perkawinan akibat poligami menurut KHI dan mazhab Syafi'i?

\section{Pembahasan}

\section{Pembatalan Perkawinan Akibat Poligami Menurut KHI dan Mazhab Syafi'i}

Produk hukum para petinggi negara, apabila tidak sesuai atau bahkan bertentangan dengan nilai-nilai yang diyakini kebenarannya oleh masyarakat, justru memunculkan kesulitan dalam pengaplikasiannya. Konsekwensi yang lebih buruk, hukum tersebut dapat menjadi penyebab pertentangan antara masyarakat dengan pemerintah, sebab masyarakat memandang pemerintah telah menyimpang dari nilai-nilai kebenaran. Begitu juga sebaliknya, apabila produk hukum mencerminkan nilai-nilai kebenaran, keadilan dan kepribadian masyarakat, maka akan menjadikan masyarakat yang tertib hukum, karena hukum itu mudah diterima sehingga mudah pula untuk diaplikasikan. Di samping itu, hukum akan memiliki kewibawaan dan pengaruh dalam kehidupan masyarakat apabila memiliki alasan-alasan sebagai dasar penetapannya. Masyarakat merasa terlindungi hak-hak dan kebutuhannya dengan keberadaan payung hukum yang jelas. Dengan demikian, keberlangsungan maslahat dapat terjamin. Penting dipahami bahwa mașlahat adalah acuan utama dan kerangka kebijakan untuk memandu kebijakan-kebijakan legislasi dan keputusan-keputusan yudikasi. Dalam dunia Islam kontemporer sekarang sedang marak upaya reformasi hukum keluarga. Tujuan upaya ini dapat dikelompokkan menjadi tiga kategori. Pertama, dan merupakan kelompok umum, negara yang bertujuan untuk unifikasi hukum perkawinan. Usaha unifikasi ini dilakukan karena terdapat sejumlah mazhab yang berlaku di negara yang bersangkutan. Kedua, untuk peningkatan status atau martabat wanita. Meskipun tujuan ini tidak disebutkan secara implisit, namun dapat dilihat dari sejarah legislasinya, yang di antaranya untuk merespons tuntutan- 
tuntutan peningkatan status wanita. Undang-undang Perkawinan Mesir dan Indonesia adalah contoh yang masuk dalam kelompok kedua ini. Dan ketiga, untuk merespons perkembangan dan tuntutan zaman, karena doktrin fikih tradisional dianggap kurang mampu mengakomodirnya. Tujuan ketiga ini merupakan tujuan mayoritas dari reformasi Undang-undang Perkawinan di negara-negara muslim, meskipun tidak menut up kemungkinan di beberapa negara mencakup beberapa tujuan sekaligus. ${ }^{4}$

Dalam konteks keindonesiaan, upaya reformasi ini melahirkan UUP 1/1974 dengan format perundangundangan dan Kompilasi Hukum Islam dengan format Instruksi Presiden. Apabila dibandingkan dengan fikih konvensional yang terdapat pada literatur-literatur klasik, upaya reformasi hukum Islam Indonesia lebih menekankan adanya aspek kesetaraan gender, yang dalam uraian sebelumnya diungkapkan dengan istilah 'peningkatan status wanita'. Kondisi ideal masyarakat Islam Indonesia dewasa ini memang menuntut terwujudnya peraturan demikian. Dengan upaya ini, diharapkan kesenjangan martabat antara pria dan wanita dapat terkikis, karena hakhak dan kemaslahatan kaum wanita mendapatkan payung hukum yang jelas dan sah di hadapan negara. Dalam kaitannya dengan penelitian ini, masalah poligami merupakan salah satu subyek yang mendapat perhatian khusus. Hal ini karena poligami bersinggungan erat dengan hak-hak dan kemaslahatan wanita. Poligami, sebagaimana diutarakan sebelumnya, diatur dalam Pasal 55-59 KHI. Materi-materinya antara lain mengenai batas maksimal jumlah istri, syarat-syarat, alasan-alasan dan prosedur pengajuan izin poligami. Apabila terjadi pelanggaran terhadap ketentuan ini, maka upaya pembatalan perkawinan dapat diajukan oleh pihak yang merasa dirugikan dengan adanya poligami ilegal tersebut. Keabsahan pembatalan ini memperoleh payung hukum dari Pasal 71 Huruf (a) KHI yang juga dinaungi oleh Pasal 24 UUP 1/1974 sebagai perundang-undangan yang lebih tinggi

${ }^{4}$ Asmawi, "Kriminalisasi Poligami dalam Hukum Keluarga di Dunia Islam Kontemporer", makalah tidak dipublikasikan, hlm.2. 
dan bersifat lebih mengikat. Upaya pembatalan poligami ini sebenarnya juga termasuk dalam kerangka peningkatan status wanita, karena pada dasarnya pihak yang paling dirugikan dengan terjadinya poligami ilegal adalah kaum wanita. Apabila dicermati lebih dalam, ketentuan Pasal 71 Huruf (a) merupakan langkah lanjutan dari pembahasan poligami pada Pasal 56 Ayat (1), yang di dalamnya disebutkan seorang suami yang hendak beristri lebih dari satu harus mendapat izin dari Pengadilan Agama. ${ }^{5}$ Artinya, adanya perkawinan poligami yang dapat dibatalkan berawal dari pelanggaran ketetapan KHI, khususnya Pasal 56 Ayat (1).Keberadaan materi Pasal 71 Huruf (a) ini dengan istilah langkah preventif sekaligus solutif. Satu sisi, pasal ini menjadi semacam peringatan keras bagi suami yang akan melakukan poligami ilegal. Dan pada sisi lain, menjadi satu jalan keluar bagi poligami ilegal yang terlanjur berlangsung.

Sebagaimana yang telah dijelaskan sebelumnya, bahwa ketetapan pasal pembatalan ini memiliki dua landasan untuk dinyatakan sebagai satu aturan yang mengikat, yaitu landasan yuridis yang berkaitan dengan payung hukum keberadaan KHI itu sendiri, dan landasan fungsional yang menitikberatkan kebutuhan nyata masyarakat Islam Indonesia yang mengalami perubahan seiring perkembangan zaman. Landasan yuridis yang dimaksud adalah Instruksi Presiden Nomor 1 Tahun 1991 yang dilanjutkan dengan Putusan Menteri Agama Nomor 154 Tahun 1991. Begitu juga fakta KHI merupakan upaya lanjutan dalam mengoptimalkan keberlakuan UUP 1/1974 atas masyarakat Islam menjadi satu keniscayaan sendiri bahwa KHI, tidak terkecuali materi Pasal 71 Huruf (a), berpijak kuat secara yuridis. Sedangkan landasan fungsionalnya adalah kebutuhan masyarakat terhadap kepastian hukum dan ketertiban umum. Perubahan hukum sendiri sangat dipengaruhi oleh kondisi dan situasi sosiologis hukum itu diaplikasikan semata-mata agar hukum dapat menjadi satu langkah cermat dalam rangka

5 Direktorat Jenderal Pembinaan Kelembagaan Agama Islam, Kompilasi Hukum Islam, hlm. 34. 
pemecahan problematika yang dihadapinya. Perubahan ini telah sejak berlangsung lama, dari satu tatanan masyarakat menuju tatanan lainnya dalam masa yang berbeda. Dan realitanya, hal ini juga dialami oleh masyarakat Islam klasik ketika itu. Mereka menyebut pernyataan ini dengan tagayyur al-ạ̣kām bi tagayyur al-amkān wa al-azminah wa al-ḥàl. Selain dua landasan ini, pencantuman pasal ini juga berdasarkan pada kaidah fikih yang diakui keabsahannya oleh seluruh ulama, termasuk kalangan mazhab Syafi'i sendiri. Kaidah tersebut adalah:

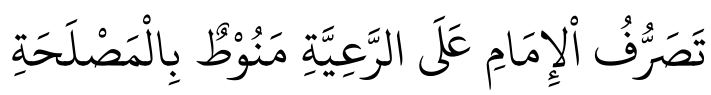

"Kebijakan pemerintah atas kepentingan masyarakat harus selalu menitikberatkan pada aspek maslahah."6

Dalam ungkapan yang lebih umum, Tājuddin alSubkiy menyebutnya:

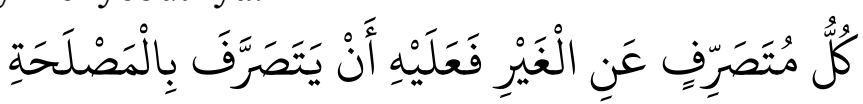

"Tiap-tiap orang yang memegang hak tasaruf orang lain, harus mentasarufkannya berdasar mashlahah. "7

Pada prinsipnya, pembatalan perkawinan dalam KHI terbagi menjadi dua kategori. Masing-masing kategori di kelompokkan dalam satu pasal. Kategori ini mencakup batal demi hukum, yang tercantum dalam Pasal 70 KHI, dan dapat dibatalkan, sebagaimana model perkawinan yang ada pada Pasal 71 KHI. Pengertian kategori pertama bahwa perkawinan tersebut harus dibatalkan atas kekuatan hukum karena menyalahi aturan-aturan yang jelas. ${ }^{8}$ Ini misalnya seperti perkawinan sedarah. Pembatalan seperti ini tidak memerlukan putusan pengadilan. Adapun kategori kedua berarti bisa batal atau bisa pula tidak. Istilah dapat dibatalkan dalam KHI berarti dapat difasidkan menjadi relatif nietig. Dengan demikian, perkawinan yang dapat

\footnotetext{
${ }^{6}$ Jalāluddīn ibn AbūBakar al-Suyūṭiy, Al- 'Asybāh wa al-Ną̣āir, (Beirut: Dār al-Kutub al-'Ilmiyyah, 2005), vol. I, hlm. 269.

${ }^{7}$ Tājuddīn ibn 'Aliy al-Subkiy, Al-'Asybāh wa al-Naẓāir, (Beirut: Dār alKutub al-'Ilmiyyah, 1982), vol. I, hlm. 310.

${ }^{8}$ Ahmad Azhar Basyir, Hukum Perkawinan Islam,(Yogyakarta: UII Press, 2007),hlm. 86.
} 
dibatalkan berarti sebelumnya telah terjadi perkawinan kemudian dibatalkan karena adanya pelanggaran terhadap aturan-aturan tertentu. ${ }^{9}$ Kategori kedua ini memerlukan putusan pengadilan untuk membuktikan kelayakan pembatalannya. Termasuk dalam kategori ini adalah poligami yang dilangsungkan tanpa seizin Pengadilan Agama.

Terdapat dua pendapat para pakar hukum Indonesia dalam memberi penilaian terhadap poligami ilegal yang dibatalkan pengadilan. Ibrahim Husain menyatakan perkawinan tersebut tetap sah karena telah memenuhi syarat dan rukun perkawinan yang ditentukan syara'. Syarat dalam poligami hanya pada kesanggupan berlaku adil. Itupun bukan syarat hukum, melainkan syarat agama sesuai tuntutan agama yang diyakini. ${ }^{10}$ Sebaliknya, Yahya Harahap, sebagaimana yang dikutip Supardi Mursalin, menyatakan bahwa poligami tanpa izin pengadilan berhukum tidak sah. Oleh karenanya poligami ini dapat dibatalkan setelah hakim memeriksa perkara tersebut secara teliti. ${ }^{11}$ Bahkan Hasan Basri pernah mengklaim semua ulama; Nahdlatul Ulama, Muhammadiyyah dan Persis sepakat terhadap ketidakabsahan perkawinan umat Islam Indonesia yang menyalahi aturan perundangundangan yang berlaku di Indonesia. ${ }^{12}$

Mempertimbangkan kedua pendapat yang berbeda di atas, terasa pendapat kedua yang lebih dominan. Pendapat pertama benar adanya apabila belum ada peraturan pemerintah yang mengatur tentang poligami. Oleh karena masalah poligami telah diatur pemerintah sedemikian hingga, maka syarat adil berubah menjadi syarat hukum. Hal ini karena keputusan pemerintah itu bersifat mengikat untuk dilaksanakan, dan berfungsi untuk menetralisir perbedaan pendapat. Dengan pertimbangan di atas, Pasal 71 Huruf (a) KHI tentang pembatalan poligami ilegal dapat

9 Martiman Prodjohamidjojo, Hukum Perkawinan Indonesia,(Jakarta: Indonesia Legal Center Publishing, 2002), hlm. 25.

10 Supardi Mursalin, Menolak Poligami, (Yogyakarta: Pustaka Pelajar, 2007), hlm. 52.

${ }^{11}$ Ibid., hlm. 54.

${ }^{12}$ Ibid., hlm. 56.

Tafaqquh; Vol. 1 No. 2, Desember 2013 
dinyatakan memiliki daya ikat bagi masyarakat Islam Indonesia selama berperkara dalam pengadilan. Sebab apabila tidak ada pihak yang mengajukan pembatalan perkawinan ini kepada Pengadilan Agama, maka perkawinan poligami tersebut tidak dapat dibatalkan, mengingat tidak ada pihak yang merasa dirugikan oleh perkawinan ini. Terlebih lagi, sifat pembatalan ini hanya pada tataran 'dapat dibatalkan', bukan 'batal demi hukum'. Disamping alasan ini, pendapat kedua lebih menjamin untuk menciptakan masyarakat yang patuh hukum sehingga prinsip dasar adanya hukum dapat terealisasi. Apalagi UUP 1/1974 menentukan bahwa sahnya suatu perkawinan diperoleh pihak yang melangsungkannya apabila mengikuti ketentuan-ketentuan agama dan memenuhi syarat-syarat yang dibutuhkan dalam perundang-undangan yang berlaku. Oleh karenanya, adanya poligami yang tidak memperhatikan prosedur-prosedurnya dianggap tidak sah, dan dapat diajukan pembatalannya.

Berkaitan dengan produk hukum yang telah dieksplorasi oleh ulama mazhab Syafi'i, khususnya masalah pembatalan perkawinan, memiliki persamaan karateristik dengan produk KHI. Secara garis besar, hal ini terdapat pada klasifikasi pembatalan itu sendiri. Dalam fikih mazhab Syafi'i terdapat istilah fasakh qahriy, sebagaimana ungkapan al-Zarkashiy, untuk perkawinan yang batal demi hukum menurut KHI. Jenis-jenis perkawinan yang dibatalkan sesuai dengan klasifikasi inipun juga sama. Dan keberlakuan pembatalannya, baik menurut mazhab Syafi'i maupun KHI, tidak memerlukan putusan hakim, karena sudah batal sejak semula. Sedangkan untuk pembatalan akibat adanya penghalang yang dianggap berdampak buruk terhadap kelangsungan rumah tangga, dalam fikih mazhab Syafi'i disebut juga dengan khiyār fasakh atau fasakh ikhtiyārí. Istilah khiyār (options) di sini sangat ditekankan, mengingat pelaku perkawinan diberi kewenangan mutlak antara memilih keberlangsungan rumah tangga (imdā', al'aqd) atau memutuskannya (faskh al-'aqd). Dalam materi KHI, konsepsi ini juga diadopsi dengan istilah 'dapat dibatalkan'. Dan jenis perkara seperti ini membutuhkan peran pengadilan guna membuktikan fakta-fakta hukum 
yang dijadikan alasan pembatalannya. Namun ada perbedaan mendasar antara produk hukum fikih mazhab Syafi'i dan salah satu rumusan yang terdapat dalam KHI. Dalam literatur-literatur klasik mazhab Syafi'i, secara tekstual, belum ditemukan praktik poligami ilegal menjadi alasan pembatalan perkawinan. Dalam rumusan Pasal 71 Huruf (a) KHI disebutkan bahwa poligami tanpa izin pengadilan dapat dibatalkan. Padahal penyusunan KHI mayoritas berasal dari literatur-literatur fikih mazhab Syafi'i.

Asumsi sementara, perbedaan produk hukum ini wajar adanya. Apa yang telah dirumuskan oleh fikih mazhab Syafi'i ketika itu sebatas perkara-perkara yang zanniy al-dilālah. Ini artinya bahwa rumusan-rumusan tersebut masih memiliki peluang mengalami perubahan ataupun penambahan apabila tidak sesuai dengan sasarannya. Begitu juga rumusan pada Pasal 71 Huruf (a) KHI beranjak dari masalah yang zanniy al-dilālah yang sesuai dengan zaman KHI tersebut berlaku. Oleh karena itu, rumusan-rumusan ini tidak dapat dikatakan sebagai hal yang bertolak belakang, mengingat sasaran hukumnya berbeda. Dan juga bukanlah rumusan-rumusan yang dapat diberlakukan selamanya, mengingat produk-produk hukum ini tidak bersifat qat 'iy al-dilālah yang hanya berkutat pada ranah ritual-ritual mahdah, sehingga layak apabila diasumsikan dengan menyatakan produk-produk hukum ini mungkin tidak memiliki kelayakan lagi diterapkan pada masa-masa berikutnya. Pangkal perbedaan ini terletak pada faktor sosiologis kemasyarakatan. Pada situasi dan kondisi produk-produk hukum mazhab Syafi'i dikeluarkan, kedudukan wanita masih jauh di bawah pria. Hal ini karena dalam tatanan masyarakat pada masa itu sistem patriarkat terasa sangat dominan. Dalam segala sendi kehidupan, istri lebih berperan di dalam rumah sebagai pelayan suami sehingga sisi maskulinitas suami begitu menonjol. Selain itu, seringnya peperangan juga memiliki pengaruh besar. Pada masa itu kaum wanita kawasan yang kalah perang menjadi tawanan, sehingga mereka diperlakukan semenamena. Ini yang menjadikan martabat wanita semakin rendah. Oleh karenanya, produk-produk hukum yang 
diterapkan juga bersesuaian dengan pola hidup masyarakat ketika itu. Sedangkan dewasa ini, setidaknya mulai abad ke-20, kedudukan wanita menjadi diskursus yang serius diperbincangkan di berbagai negara. Isu-isu kesetaraan gender banyak digulirkan. Kaum wanita lebih leluasa dalam menuntut peran mereka dalam sendi-sendi masyarakat. Ini yang menyebabkan beberapa negara mereformasi materi perundang-undangan keluarga, tidak terkecuali negara-negara Islam, termasuk Indonesia. Dan salah satu tujuan utamanya adalah memberi payung hukum terhadap kedudukan kaum wanita, baik dalam keluarga maupun sosial kemasyarakatan. Untuk itu, para pakar hukum Islam Indonesia dituntut mengeksplorasi intelektualitas mereka semaksimal mungkin agar produkproduk hukum Islam sesuai kebutuhan masyarakat Islam Indonesia. Salah satu hasilnya dapat dilihat dari rumusan Pasal 71 Huruf (a) KHI tentang pembatalan perkawinan akibat poligami ilegal.

\section{Relevansi Pembatalan Perkawinan Akibat Poligami Menurut KHI dan Fikih Mazhab Syafi'i}

Dinamika yang muncul di tengah kehidupan masyarakat mengalami perubahan secara cepat seiring faktor perkembangan zaman. Berdasarkan realitanya, perubahan ini terjadi di setiap aspek kehidupan. Persoalan hukum menjadi salah satu hal yang seharusnya di prioritaskan dalam mengimbangi perkembangan tersebut. Idealnya, semakin berkembang tatanan masyarakat, semakin berkembang pula tatanan hukumnya. Sebab tidak dapat dipungkiri bahwa keberadaan hukum menjadi alat kontrol di dalamnya, dan sangat menentukan kemajuan peradaban masayarakat itu sendiri.

Dengan adanya hukum yang relevan, konstruksi sosial yang aman, tertib dan adil dapat terjaga keberlangsungannya. Sebaliknya, apabila terjadi stagnasi hukum, dapat dipastikan kehidupan masyarakat yang ideal tidak akan pernah terwujud. Oleh karena itu, para ahli hukum dituntut untuk serius dalam melakukan telaah dan kajian ulang terhadap berbagai dasar hukum yang selama ini dijadikan rujukannya. Disamping itu, tuntutan itu 
merupakan wujud upaya revitalisasi hukum Islam yang dicita-citakan sebagai jalan alternatif untuk menginformasikan kejelasan berbagai masalah yang dihadapi masyarakat.

Pada tatanan fungsional itu, hukum Islam ditempatkan sebagai piranti atau alat pembaharuan sosial. Hukum Islam mengantarkan masyarakat secara normatif untuk membedah dan mendekonstruksi hal-hal yang dipandang merugikan, menghambat dan menghancurkan segi-segi kehidupan. Untuk mengukuhkan peran itu, eksistensi hukum Islam diujiketika perubahan-perubahan yang terjadi tidak hanya sebatas evolutif, namun semakin dekat ke arah revolutif.

Dalam ranah hukum keluarga Islam Indonesia, Kompilasi Hukum Islam dengan berbagai topik materinya menjadi contoh penjelasan di atas. Kompilasi Hukum Islam yang dikenal sebagai fikih 'made in Indonesia' adalah bentukhukum Islam yang sesuai dengan karakteristik masyarakat Islam Indonesia. Oleh karenanya, dalam pengaplikasiannya KHI dijadikan pijakan bagi para hakim di Pengadilan Agama dalam memutuskan perkara-perkara keluarga. Tidak terkecuali mengenai persoalan pembatalan perkawinan akibat poligami tanpa izin Pengadilan Agama yang menjadi pokok bahasan dalam penelitian ini.

Persoalan pembatalan poligami ini disamping sebagai langkah lanjutan dari pelanggaran terhadap syarat-syarat formil berpoligami, juga menjadikan teori maslahah atau istișlāh sebagai landasan utamanya. Penekanan aspek maslahah ini merupakan tujuan yang dicita-citakan Islam, yang diantaranya meliputi pencapaian kepentingan dan keunt ungan publik.

Terlebih pembatalan ini hanya menjadi wewenang institusi pemerintah, tepatnya Pengadilan Agama. Artinya bahwa jika dihubungkan dengan kaidah fikih yang tercantum di atas, aspek kemaslahatan masyarakat menjadi penting untuk diprioritaskan dalam kebijakan-kebijakan pemerintah. Bahkan dalam Undang-undang Perkawinan negara-negara Islam kontemporer, seperti: Turki, Pakistan dan Tunisia, pelanggaran poligami tidak hanya mengakibatkan pembatalan perkawinan, melainkan juga 
dikategorikan sebagai tindak pidana para pelakunya.

Sementara itu, meskipun dalam khazanah Syafi'iyyah klasik tidak tercantum prosedur poligami, namun semua ulama sepakat bahwa mu'āsyarah bi al-ma'rüf adalah konsep yang menjadi keharusan bagi suami istri. Ini mengindikasikan konsep tersebut mengandung kelayakan untuk mewujudkan kemaslahatan bersama. Dan terwujudnya kemaslahatan inilah yang menjadi tujuan utama. Konsep ini juga berkesinambungan erat dengan kaidah al-ḍarar yuzālu, sehingga apabila konsep mu'āsyarah bi al-ma'rüf ini terwujud, maka kemadlaratan dalam rumah tangga tidak pernah terjadi.

Adapun prosedur poligami yang dimaksud di atas meliputi kesanggupan berlaku adil, persetujuan istri untuk bersedia dimadu dan persetujuan Pengadilan Agama sebagai pihak yang memiliki otoritasi mengatur hukum kekeluargaan di Indonesia. Dalam hal prosedur tersebut dilanggar, maka indikasi tidak adanya mu'āsyarah bi alma'rūf semakin besar.

Dengan ungkapan lain, suami yang melakukan poligami tanpa izin bukanlah suami yang baik, karena dia tidak menjalankan konsep mu'āsyarah bi al-ma'rūf dalam keluarganya. Dengan demikian menjadi jelas, istri dan keluarga adalah pihak-pihak yang dirugikan oleh perilaku suami. Ini berarti juga istri masuk dalam kriteria kondisi darar. Padahal jelas bahwa kondisi ini sesegera mungkin harus di netralisir agar tidak berdampak lebih buruk lagi. Oleh karenanya, tindakan solutif yang dapat dioptimalkan adalah pembatalan perkawinan poligami ini. Hal inilah yang dinilai cukup efektif untuk mengurangi kemadlaratan yang ada.

Sebenarnya, menurut analisis yang ada, segala hal yang dijadikan alasan utama adanya faskh ikhtiyāri dalam produk-produk Syafi'iyyah klasik bermuatan adanya ḍarar yang dialami pihak-pihak yang terlibat di dalam perkawinan. Sangat terlihat jelas, misalnya, impotensi bermuatan darar bagi seorang istri dalam kehidupan rumah tangganya. Bentuk darar dalam hal ini adalah suami tidak mampu memenuhi kebutuhan biologis istri secara sempurna. Kondisi demikian, oleh Syafi'iyyah, dinyatakan 
sebagai salah bentuk ḍarar yang dialami istri. Oleh karenanya, istri memiliki peluang untuk menggunakan hak khiyār-nya sebagai upaya penafian ḍarar yang dialaminya. Dengan asumsi inilah, dinilai bahwa poligami tanpa izin juga layak untuk diajukan pembatalannya. Sebab, poligami yang demikian berdampak besar memicu terjadinya darar terhadap pihak istri.

Bahkan, dalam satu rumusan produk hukum mazhab Syafi'i terdapat kewenangan pembatalan akibat kebohongan status salah satu pihak. Rumusan ini, membuka penafsiran bahwa pelaku poligami ilegal juga dapat masuk di dalamnya. Sebab tidak menutup kemungkinan dalam tataran realitanya, suami mengaku masih perjaka agar perkawinan keduanya mendapat legalitas.

Dengan demikian, relevansi ketetapan KHI ini dengan fikih mazhab Syafi'i terletak pada istinbāt alạ̣kām. Artinya, dasar pijakan yang dipakai oleh para perumus KHI dalam permasalahan pembatalan ini menggunakan metodologi penggalian hukum istiṣlāh yang juga dianut oleh kalangan mazhab Syafi'i, bukan sebatas pada produk-produk hukumnya. Lebih luas lagi, bahwa ijtihad atau penggalian hukum yang dilakukan oleh para perumus KHI dan ulama Syafi'iyyah semata-mata bertujuan untuk mewujudkan kemaslahat an bersama.

Sedangkan alasan yang tepat untuk perbedaan produk hukum ini adalah karena pendapat fuqaha', dalam hal ini kalangan mazhab Syafi'i, dan pendapat para perumus KHI sudahsesuai dengan situasi dan kondisinya masing-masing. Bahkan jauh sebelum KHI lahir, Zakariyya al-Anșāriy menegaskan tidak adanya keseragaman hukum di antara para ahli fikih itu dikarenakan pengaruh situasi dan kondisi serta social budaya masyarakat yang dihadapi. ${ }^{13}$

${ }^{13}$ Abū Zakariyya al-`Anșāriy, Lubb al-Ușūl fi Gāyah al-Wuṣūl, (Surabaya: Al-Hidayah, t.t.), hlm. 42. 


\section{Kesimpulan}

Dasar dan latar belakang para perumus Kompilasi Hukum Islam dalam menetapkan keabsahan pembatalan perkawinan terhadap poligami tanpa izin Pengadilan Agama adalah untuk menciptakan kepastian hukum dan ketertiban umum demi kemaslahatan bersama, terutama perlindungan terhadap kaum wanita sebagai pihak yang dirugikan atas adanya poligami ilegal. Adapun dalam literatur-literatur mazhab Syafi'i, tidak satupun ditemukan adanya kewenangan pembatalan perkawinan akibat poligami ilegal. Sedangkan perbedaan antara ketetapan Pasal 71 Huruf (a) KHI dan ketetapan fikih mazhab Syafi'i disebabkan tidak adanya ayat Al-Qur'an dan Hadits Nabi SAW yang menjelaskan secara terperinci tentang permasalahan ini, sehingga dituntut melakukan pengkajian yang mendalam agar permasalahan ini mendapat porsi hukum yang proporsional. Selain itu, perbedaan waktu dan tempat serta kondisi sosial kemasyarakatan yang dihadapi mempengaruhi hasil ijtihad mereka. Dengan demikian menyebabkan kebijakan dan produk hukum yang berbeda pula. 


\section{Daftar Pustaka}

Subkiy, Tājuddin ibn 'Aliy (al). Vol, 1. Al-Asybāh wa alNazāir, Beirut: Dār al-Kutub al-'Ilmiyyah, 1982,

Suyūtịy, Jalāluddīn ibn Abū Bakar (al). Vol, 1. Al-Ashbāh wa al-Nazāir, Beirut: Dār al-Kutub al-'Ilmiyyah, 2005.

Anșāriy, Abū Zakariyya (al), Lubb al-Ușūl fi Gāyah al-Wuṣūl, Surabaya: Al-Hidayah, t.th.,

Asmawi, "Kriminalisasi Poligami dalam Hukum Keluarga di Dunia Islam Kontemporer", makalah tidak dipublikasikan.

Basyir, Ahmad Azhar, Hukum Perkawinan Islam, Yogyakarta: UII Press, 2007.

Direktorat Jenderal Pembinaan Kelembagaan Agama Islam, Kompilasi Hukum Islam di Indonesia, Jakarta: Departemen Agama R.I., 2001.

Mursalin, Supardi, Menolak Poligami, Yogyakarta: Pustaka Pelajar, 2007.

Prodjohamidjojo, Martiman, Hukum Perkawinan Indonesia, Jakarta: Indonesia Legal Center Publishing, 2002.

Sumitro, Warkum, Perkembangan Hukum Islam di Tengah Dinamika Sosial Politik di Indonesia, Malang: Bayumedia, 2005.

Sunardi, Sukris, Trasendensi Keadilan Hukum Waris dalam Islam Transformatif, Semarang: Toha Putra, 1991. 